\title{
Evaluation of Pig Dung for Electricity Generation Using Microbial Fuel Cell
}

\author{
Adegunloye Deke Victoria Faloni Taiwo Mercy* \\ Department of Microbiology, Federal University of Technology, Akure, Ondo State, Nigeria
}

\begin{abstract}
Pig dung was evaluated for electric current and voltage generation using microbial fuel cell (MFC). Pig dung was collected from three different animal farms; FUTA, Air Force and Apatapiti Extension. Isolation and identification of microorganisms from pig dung was carried out before and after electric current and voltage generation using conventional techniques. Physicochemical composition were determined using standard methods. Microbial fuel cells (MFCs) chambers were fabricated. The circuit was completed with electrodes and flexible wires for electron transfer from the anode to the cathode. Pig dung was used as the anolyte while water was used in the cathode as the electron acceptor. Current and voltage were measured in the morning, afternoon and evening for 40 days using the digital multimeter. The result revealed sixteen microorganisms: Enterobacter cloacae, Escherichia coli, Shigella sp, Citrobacter gillenii, Klebsiella singaporensis, Paenibacillus septentrionalis, Bacillus circulans, Salmonella spp, Enterobacter asburiae, Yersinia intermedia, Yersinia enterocolitica, Fusarium sp, Aspergillus flavus, Aspergillus funmigatus, Aspergillus niger, and Penicillium chrysogenum. The highest bacterial and fungal population; $2.71 \times 10^{5} \mathrm{cfu} / \mathrm{g}$ and $1.47 \times 10^{4} \mathrm{sfu} / \mathrm{g}$ were observed from Air Force and FUTA pig dung respectively before current and voltage generation. The highest bacterial and fungal population; $1.35 \times 10^{5} \mathrm{cfu} / \mathrm{g}$ and $1.60 \times 10^{4}$ sfu/g were observed from Apatapiti Extension and FUTA pig dung respectively after current and voltage generation. The highest current and voltage; $0.319 \pm 0.00 \mathrm{~mA}$ and $572.333 \pm 3.84 \mathrm{mV}$ were generated from Apatapiti Extension and Air-Force pig dung. Sterilized pig dung (control) generated a low voltage and current affirms the important role of microorganisms in voltage and current generation. In conclusion, pig dung can be used to generate electrical current and voltage owing to microbial activities present in the pig dung. A nuisance causing waste such as pig dung can serve as a renewable source of energy for electricity generation, this will simultaneously help to resolve the problems of environmental toxics that oozes from its disposal and ultimately serve as a way of mitigating global warming in the world.
\end{abstract}

Keywords: Pig dung, Microbial fuel cell (MFC), current, voltage.

DOI: $10.7176 / \mathrm{JETP} / 10-1-02$

Publication date: January $31^{\text {st }} 2020$

\subsection{Introduction}

Energy is a central factor in the advancement and development of the socioeconomic sector of any nation and uninterrupted power supply is a crucial issue for all countries today (Oyedepo, 2012). Globally, the use of fossil fuel (coal, diesel fuel, gasoline, oil, and natural gas) for electricity supply, heating, transportation, and industry has recently increased with the resultant effect as global energy crisis (Franks and Nevin, 2010). New methods of electricity generation from carbon-free renewable energy sources is an important research area for alternative power systems (Fan and Xue, 2016). Studies conducted on a wide range of energy solutions revealed that no solution appears to replace fossil fuels in totality. Owing to this, various alternatives needs to be sourced for in mitigating this major challenge knowing that reliance on fossil fuels is unsustainable due to pollution and finite supplies (Franks and Nevin, 2010). Microbial fuel cell (MFC) has emerged as a technology capable of meeting the dual goals of waste management and energy production in a sustainable way thereby resolving environmental and energy crisis (Fan and Xue, 2016). MFC is drawing wide attention due to its projected use to recover energy in the form of electricity (Cao et al., 2019). The need for more animal protein to sustain an exponentially increasing population has led to a noticeable increase in livestock production over the years with various scales of animal farms been set up. This has invariably resulted to the colossal increase in animal dung consequently posing waste management as a challenge to be resolved (Iregbu et al., 2014). The use of pig dung in a microbial fuel cell as an additional alternative for electricity generation will advantageously lead to a drastic reduction in its volume in the environment, minimize the problems associated with its disposal such as environmental pollution, and create wealth and employment (Onuorah et al., 2017). Present global energy crises are the results of growing demand for fossil fuels (particularly oil, coal and gas) resulting into harmful environmental effect and inadequate electricity supply. There is therefore a need for evaluating newer sources of energy in meeting this growing demand knowing that future economic growth crucially hinge on this and new methods of electricity generation from renewable resources without a net Green House Gases (GHG) emission are much desired (Cao et. al., 2019). 


\subsection{Materials and Methods \\ 2.1 Study area}

The location of study

\section{Collection of Samples from Study Area}

Fresh morning pig dung was collected from three medium-scale pig farms within FUTA area of Akure, Ondo state. These three locations are; FUTA, Air Force and Apatapiti. The sample was collected into sterile bags, the samples were well labelled and transported aseptically to the Microbiology Laboratory, Federal University of Technology, Akure for analyses immediately.

\section{Physicochemical analysis}

Physicochemical parameters including $\mathrm{pH}$, electrical conductivity (EC), Total organic matter concentrations of ammonia, calcium, magnesium, sodium, potassium, total nitrogen, copper, zinc were determined using Hanna Instrument for $\mathrm{pH}, \mathrm{EC}$, Atomic Absorption Spectrophotometer (AAS) Buck Scientific 210 VGP for the mineral composition and Conductivity Measuring Bridge (CDM210) for EC.

\section{Isolation of Microorganism}

Isolation of the microorganisms were carried out according to the method described by Fawole and Oso (2012). One gram of the pig manure was measured using a weighing balance and a sterile foil paper into a test tube. Ten folds serial dilution of the sample was carried out using sterile distilled water. One millilitre aliquot of the diluted sample $\left(10^{3}\right.$ and $\left.10^{6}\right)$ was plated out using the pour plate technique into Petri dishes with $20 \mathrm{ml}$ of molten culture media (Potatoes dextrose agar, Nutrient agar, Eosin methylene blue agar, Salmonella-shigella agar and MacConkey agar). The culture media were covered and incubated in an inverted position at $37{ }^{\circ} \mathrm{C}$ for 24 hours for bacteria and $27^{\circ} \mathrm{C}$ for 48 - 96 hours for fungi in triplicate before examination for microbial growth. The bacterial isolates were purified by streaking on fresh sterile nutrient agar before subculturing. Fungal isolates were also subcultured to obtain pure isolates. The pure isolates were temporarily stored on slants and kept at $4^{\circ} \mathrm{C}$ for further use. Colony counts were carried out on plates in triplicate.

\section{Identification of Microorganism}

Identification of pure bacteria and fungi isolates were determined using cultural and morphological features. Bacteria isolates were further identified using biochemical tests according to (Cheesbrough, 2006) while fungi isolates were identified microscopically.

\section{Microbial Fuel Cell Construction \\ MFC Fabrication:}

The MFC were constructed in modification to the description of Adegunloye and Olotu (2017). The anode and cathode chambers were fabricated using screw-capped plastic containers with drilled holes on one side of each container ensuring that the holes were exactly opposite each other. The total working volume of $1200 \mathrm{ml}$ was contained in both chambers. Salt bridge (proton exchange membrane) contained in $15 \mathrm{~cm}$ length and $3.81 \mathrm{~cm}$ diameter PVC pipes were fixed into the holes of the two containers with the aid of epoxy adhesive to avoid leakage. Holes of two millimetres $(\mathrm{mm})$ in diameter were drilled on top of each plastic containers lids as wire point inputs. This set-up was filled with water past the holes/joints and allowed to stay overnight to check for possible leakages.

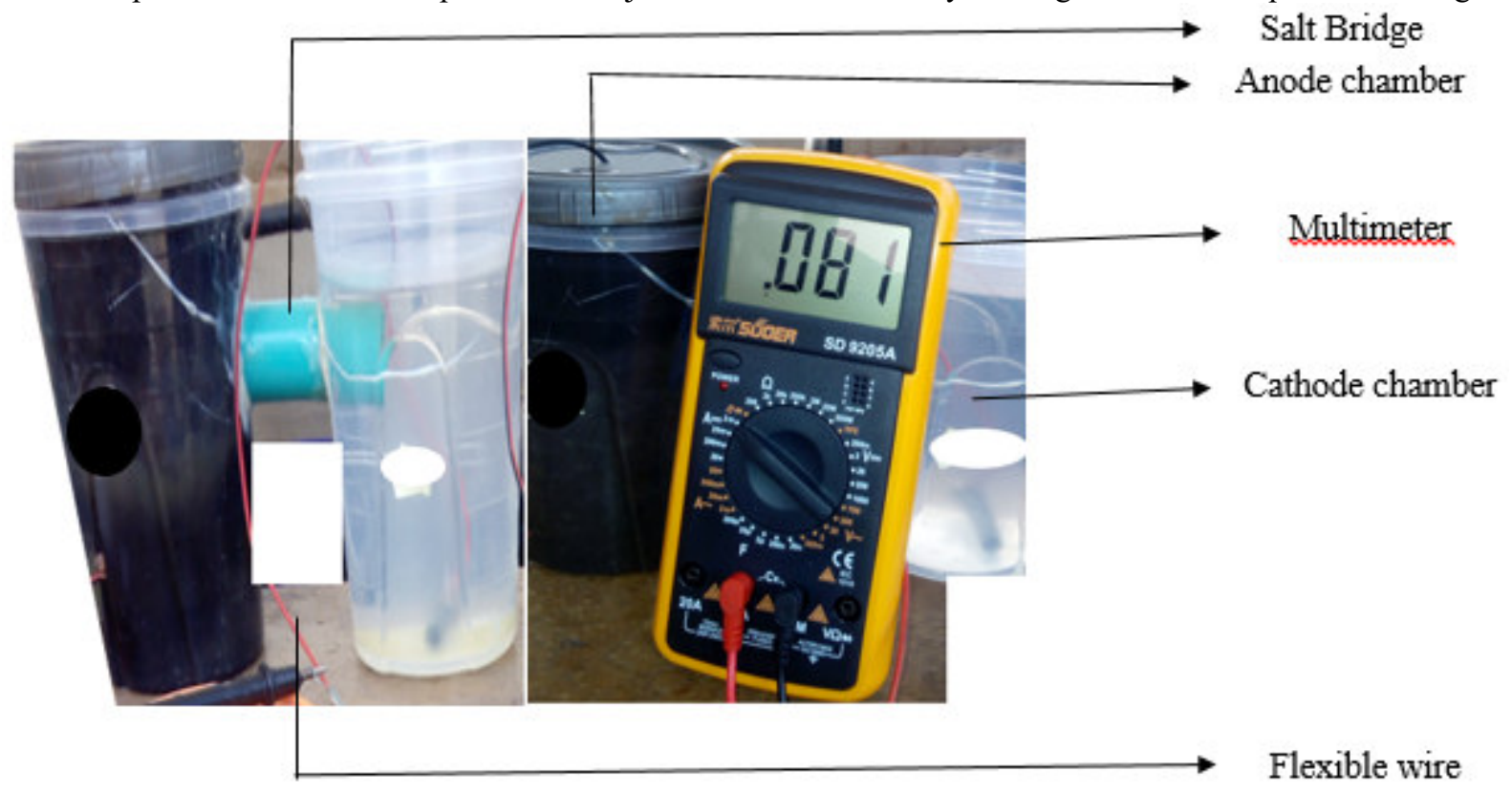


Making the Salt Bridge (Proton Exchange Membrane):

$\mathrm{NaCl}$ was used as an electrolyte for proton exchange in the salt bridge according to the work of (Liu et al., 2005; Kumar et al., 2012). Salt bridge was repared by dissolving $20 \mathrm{~g}$ of agar-agar powder into $1000 \mathrm{ml}$ of distilled water containing $75.5 \mathrm{~g} \mathrm{NaCl}$ which was boiled for about 3 minutes (Akujobi et al., 2017). While the solution was still warm, it was poured into the PVC pipes covered at one end with sterile nylon firmly held by rubber band until it was solidified.

\section{Filling the Anode Chamber of the MFC}

The constructed MFCs chambers were sterilized with ethanol (85\%) and irradiated with UV light for 15 minutes in an inoculating chamber to eliminate possible cross-contamination in the cause of its construction. The anode chamber was aseptically filled with $50 \%$ of the substrate which implies $600 \mathrm{~g}$ of pig dung with $600 \mathrm{ml}$ of sterilized distilled water (Kumar et al., 2012). One thousand two hundred (1200) $\mathrm{ml}$ of $\mathrm{H}_{2} \mathrm{O}$ was used as electron acceptor in the cathode chamber.

\section{Testing the Microbial Fuel Cell:}

The anode chambers were tightly closed and sealed so as to maintain an anaerobic condition throughout the experiment while the cathode chamber was left open for aerobic oxidation. The external circuits connection were completed with the $1.5 \mathrm{~mm}$ flexible copper wires of length $0.4 \mathrm{~m}$ fixed through the drilled holes on the cover lid into each chamber and sealed with epoxy resin to avoid corrosion of copper wire (Kim et al., 2002; Zou et al., 2007). The bare end of the copper wires was coiled around the electrodes in the respective chambers to facilitate the passage of electrons from the microbial breakdown of the substrate through the circuit. Voltage and current across each cell were recorded with the digital multimeter (SUOER SD 9205A). The observation was determined for 40 days at 6 hours interval per day, starting from 8 am to 8 pm classified as morning, afternoon and evening session.

Making and Testing of the Control MFC:

Six hundred gram of pig dung was weighed and sterilized at $121^{\circ} \mathrm{C}$ for 15 minutes using the autoclave so as to inhibit all the microorganism without denaturing its mineral and nutritional components. The pig dung was aseptically transferred into the anode container and tightly covered to prevent the penetration of oxygen $600 \mathrm{ml}$ of sterile water was used to dissolve the pig dung. The cathode was filled with distilled water. The same mode of MFC construction as above was used to construct the control MFC.

\section{Statistical Analysis}

All numerical data obtained were subjected to Analysis of Variance (ANOVA) and Duncan's New Multiple Range Test using Statistical Packages for the Social Sciences (SPSS) 22.0 version. Data are presented as mean \pm standard error (SE). For all tests, the significance was determined at the level of at $\mathrm{P} \leq 0.05$.

\section{RESULTS}

Total Aerobic Bacterial Load of Pig Dung (before and after electric current and voltage generation)

Bacterial load under aerobic condition is represented in Table 1 indicated a significant difference $(p \leq 0.05)$ in total viable bacterial counts of the three pig dung samples. Initial isolation of pig dung showed a range of $1.73 \times 10^{5}$ $\mathrm{cfu} / \mathrm{g}$ to $2.71 \times 10^{5} \mathrm{cfu} / \mathrm{g}$, there was no significant $(\mathrm{p} \leq 0.05)$ difference between Air Force and Apatapiti Extension pig dung but both were significantly $(\mathrm{p} \leq 0.05)$ higher than FUTA pig dung. The bacterial load of pig dung from MFC after current and voltage generation showed a range of $6.0 \times 10^{4} \mathrm{cfu} / \mathrm{g}$ to $1.13 \times 10^{5} \mathrm{cfu} / \mathrm{g}$ with FUTA pig dung having the highest load significantly $(\mathrm{p} \leq 0.05)$. All the samples recorded the overall highest bacterial load from initial isolation.

Total Aerobic Fungal Load of Pig Dung (before and after electric current and voltage generation)

Fungal load under the aerobic condition is represented in Table 2 indicated a significant difference $(p \leq 0.05)$ in total viable fungal counts of the three pig dung samples. The fungal load from the initial isolation showed a range of $4.00 \times 10^{3} \mathrm{cfu} / \mathrm{g}$ to $2.93 \times 10^{4} \mathrm{cfu} / \mathrm{g}$, there was no significant $(\mathrm{p} \leq 0.05)$ difference among the pig dung samples. The fungal load of the pig dung from MFC after current and voltage generation showed a range of $0.00 \mathrm{X} 10^{3} \mathrm{cfu} / \mathrm{g}$ to $1.20 \times 10^{4} \mathrm{cfu} / \mathrm{g}$ with Apatapiti Extension pig dung having the highest load significantly $(\mathrm{p} \leq 0.05)$.

\section{Total Anaerobic Bacterial and Fungal Load of Pig Dung (after electric current and voltage generation)}

Bacterial and fungal load of the pig dung after current and voltage generation incubated under the anaerobic condition shown in Table 3 indicated there was significant difference $(\mathrm{p} \leq 0.05)$ in total viable bacterial and fungal counts across the samples. The anaerobic bacterial load of the pig dung from the MFCs showed a range of $1.50 \mathrm{x}$ $10^{4} \mathrm{cfu} / \mathrm{g}$ to $4.00 \times 10^{4} \mathrm{cfu} / \mathrm{g}$. FUTA pig dung had significantly $(\mathrm{p} \leq 0.05)$ the highest anaerobic bacteria load while Air Force pig dung had the lowest from all the MFCs. The anaerobic fungal load from the MFCs showed a range of $0.00 \times 10^{3} \mathrm{sfu} / \mathrm{g}$ to $1.20 \times 10^{4} \mathrm{sfu} / \mathrm{g}$ with Apatapiti Extension pig dung having significantly $(\mathrm{p} \leq 0.05)$ the highest anaerobic fungal load among all the MFCs while FUTA pig dung had no growth.

Total Coliform Load of Pig Dung (before and after electric current and voltage generation)

Coliform load of the pig dung before and after current and voltage generation shown in Table 4 indicated there was a significant difference $(\mathrm{p} \leq 0.05)$ in total coliform counts across the samples. The coliform count of the pig 
dung from initial isolation showed a range of $3.97 \times 10^{4} \mathrm{cfu} / \mathrm{g}$ to $5.97 \times 10^{4} \mathrm{cfu} / \mathrm{g}$ with no significant $(\mathrm{p} \leq 0.05)$ difference among the pig dung samples. The total coliform count from the MFC after current and voltage generation showed a range of $4.67 \times 10^{3} \mathrm{cfu} / \mathrm{g}$ to $8.67 \times 10^{3} \mathrm{cfu} / \mathrm{g}$ with no significant $(\mathrm{p} \leq 0.05)$ difference among pig dung samples. All samples have the highest bacteria load from initial isolation.

Table 1: Total aerobic bacteria load of pig dung before and after current and voltage generation

\begin{tabular}{lll}
\hline PIG DUNG & Initial $(\mathbf{C f u} / \mathbf{g})$ & Final $(\mathbf{C f u} / \mathbf{g})$ \\
\hline FUTA & $1.73 \times 10^{5} \pm 25.44^{\mathrm{a}}$ & $1.13 \times 10^{5} \pm 2.89^{\mathrm{c}}$ \\
Air Force & $2.71 \times 10^{5} \pm 25.10^{\mathrm{b}}$ & $6.00 \times 10^{4} \pm 3.46^{\mathrm{a}}$ \\
Apatapiti Extension & $2.67 \times 10^{5} \pm 7.06^{\mathrm{b}}$ & $9.20 \times 10^{4} \pm 1.15^{\mathrm{b}}$ \\
\hline
\end{tabular}

Values are means \pm Standard error of pig dung. Values in the same column carrying the same superscript are not significantly different at ( $\mathrm{p} \leq 0.05)$ using Duncan's New Multiple Range Test

Table 2: Total aerobic fungal load of pig dung before and after current and voltage generation

\begin{tabular}{lll}
\hline Pig Dung & Initial $\left(\mathbf{S f u} / \mathbf{g} \times \mathbf{1 0}^{\mathbf{3}}\right)$ & Final $\left(\mathbf{S f u} / \mathbf{g} \times \mathbf{~ 1 0}^{\mathbf{3}}\right)$ \\
\hline FUTA & $1.47 \times 10^{4} \pm 0.88^{\mathrm{a}}$ & $0.00 \times 10^{3} \pm 0.00^{\mathrm{a}}$ \\
Air Force & $2.93 \times 10^{4} \pm 13.78^{\mathrm{a}}$ & $9.00 \times 10^{3} \pm 0.58^{\mathrm{b}}$ \\
Apatapiti Extension & $4.00 \times 10^{3} \pm 2.00^{\mathrm{a}}$ & $1.20 \times 10^{4} \pm 1.15^{\mathrm{c}}$ \\
\hline
\end{tabular}

Values are means \pm Standard error of pig dung. Values in the same column carrying the same superscript are not significantly different at $(\mathrm{p} \leq 0.05)$ using Duncan's New Multiple Range Test.

KEY:

Sfu/g- Spore forming unit per gram.

Table 3: Total anaerobic bacterial and fungal load of pig dung after current and voltage generation

\begin{tabular}{llc}
\hline Pig Dung & Bacteria $(\mathbf{C f u} / \mathbf{g})$ & Fungi $(\mathbf{S f u} / \mathbf{g})$ \\
\hline FUTA & $4.00 \times 10^{4} \pm 2.89^{\mathrm{c}}$ & $0.00 \times 10^{3} \pm 0.00^{\mathrm{a}}$ \\
Air Force & $1.50 \times 10^{4} \pm 3.46^{\mathrm{a}}$ & $9.00 \times 10^{3} \pm 0.58^{\mathrm{b}}$ \\
Apatapiti Extension & $2.20 \times 10^{4} \pm 1.15^{\mathrm{b}}$ & $1.20 \times 10^{4} \pm 1.15^{\mathrm{c}}$ \\
\hline
\end{tabular}

Values are means \pm Standard error of pig dung. Values in the same column carrying the same superscript are not significantly different at $(\mathrm{p} \leq 0.05)$ using Duncan's New Multiple Range Test.

KEY:

Cfu/g- Colony-forming unit per gram.

$\mathrm{Sfu} / \mathrm{g}$ - Spore forming unit per gram.

Table 4: Total coliform load of pig dung before and after current and voltage generation

\begin{tabular}{lll}
\hline Pig Dung & Initial $\left(\mathbf{C f u} / \mathbf{g} \times \mathbf{1 0}^{\mathbf{3}}\right)$ & Final $\left(\mathbf{C f u} / \mathbf{g ~ x ~ 1 0} \mathbf{1 0}^{\mathbf{3}}\right)$ \\
\hline FUTA & $5.97 \times 10^{4} \pm 3.67^{\mathrm{a}}$ & $8.67 \times 10^{3} \pm 1.67^{\mathrm{a}}$ \\
Air Force & $3.97 \times 10^{4} \pm 9.67^{\mathrm{a}}$ & $5.67 \times 10^{3} \pm 1.33^{\mathrm{a}}$ \\
Apatapiti Extension & $5.93 \times 10^{4} \pm 3.33^{\mathrm{a}}$ & $4.67 \times 10^{3} \pm 2.33^{\mathrm{a}}$ \\
\hline
\end{tabular}

Values are means \pm Standard error of pig dung. Values in the same column carrying the same superscript are not significantly different at $(\mathrm{p} \leq 0.05)$ using Duncan's New Multiple Range Test.

KEY: Cfu/g- Colony-forming unit per gram.

4.7 Biochemical characterization of bacterial isolates (before and after electric current and voltage generation)

The biochemical characterization of the bacteria isolated before and after current and voltage generation is represented in Tables 9 and 10. The result revealed seven bacterial isolates were identified before current and voltage generation, these include; Enterobacter cloacae, Escherichia coli, Shigella sp, Citrobacter gillenii, Bacillus circulans, Salmonella spp and Yersinia intermedia while five were identified after current and voltage generation, these include; Klebsiella singaporensis, Paenibacillus septentrionalis, Bacillus circulans, Enterobacter asburiae, and Yersinia enterocolitica.

Microscopic characterization of fungal isolates (before and after electric current and voltage generation) The microscopic characterization of fungal isolates is represented in Table 11. The result revealed six (6) isolates which are; Fusarium sp, Aspergillus flavus, Aspergillus funmigatus, Aspergillus niger, and Penicillium chrysogenum. 
Table 9: Biochemical Characterization of Bacterial Isolated from Pig Dung (before electric current and voltage generation)

\begin{tabular}{|c|c|c|c|c|c|c|c|c|c|c|c|c|c|c|c|c|c|c|c|c|c|}
\hline 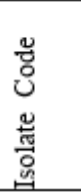 & 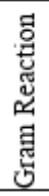 & 寻 $\frac{{ }_{0}^{\circ}}{\frac{0}{0}}$ & 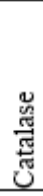 & 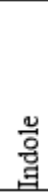 & 苋 & 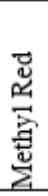 & 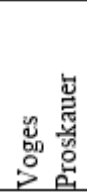 & 莺 & 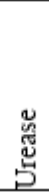 & $\begin{array}{l}\text { 톨 } \\
\text { 夏 }\end{array}$ & 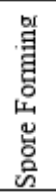 & 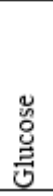 & 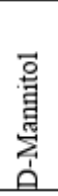 & 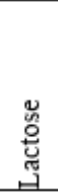 & 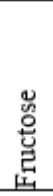 & 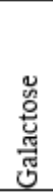 & 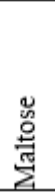 & 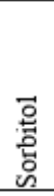 & 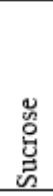 & 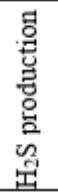 & 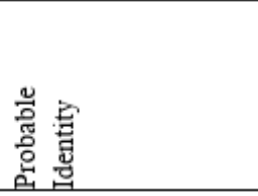 \\
\hline $6(0)$ & - & $\mathrm{R}$ & + & - & - & - & + & + & + & + & - & + & + & $+\mathrm{G}$ & + & + & - & $+\mathrm{G}$ & + & -1 & Enterobacter cloacae \\
\hline $11(0)$ & + & $\mathrm{R}$ & + & + & - & - & - & + & - & + & - & $+\mathrm{G}$ & $+\mathrm{G}$ & $+\mathrm{G}$ & $+\mathrm{G}$ & $+\mathrm{G}$ & $+\mathrm{G}$ & $+\mathrm{G}$ & + & +1 & Bacillus circulans \\
\hline $17(0)$ & - & $\mathrm{R}$ & + & + & - & - & - & - & - & - & - & + & + & $+\mathrm{G}$ & + & $+\mathrm{G}$ & $+\mathrm{G}$ & $+\mathrm{G}$ & $+\mathrm{G}$ & - & Yersinia intermedia \\
\hline $\mathrm{A} 3(0)$ & - & $\mathrm{R}$ & + & + & - & - & - & - & - & - & - & $+\mathrm{G}$ & $+\mathrm{G}$ & $+\mathrm{G}$ & $+\mathrm{G}$ & $+\mathrm{G}$ & + & + & + & + & Citrobacter gillenii \\
\hline $\mathrm{EC}$ & - & $\mathrm{R}$ & + & + & - & - & - & - & - & + & - & $+\mathrm{G}$ & $+\mathrm{G}$ & $+\mathrm{G}$ & $+\mathrm{G}$ & $+\mathrm{G}$ & $+\mathrm{G}$ & $+\mathrm{G}$ & + & +1 & Escherichia coli \\
\hline Shig & - & $\mathrm{R}$ & + & - & - & + & + & - & + & - & - & + & + & - & - & - & & - & - & - & Shigella sp \\
\hline Salm & - & $\mathrm{R}$ & + & - & - & - & - & - & - & + & - & $+\mathrm{G}$ & $+\mathrm{G}$ & $+\mathrm{G}$ & $+\mathrm{G}$ & $+\mathrm{G}$ & $+\mathrm{G}$ & $+\mathrm{G}$ & $+\mathrm{G}$ & $+s$ & Salmonella $\mathrm{sp}$ \\
\hline
\end{tabular}

Table 10: Biochemical Characterization of Bacterial Isolated from Pig Dung (after electric current and voltage generation)

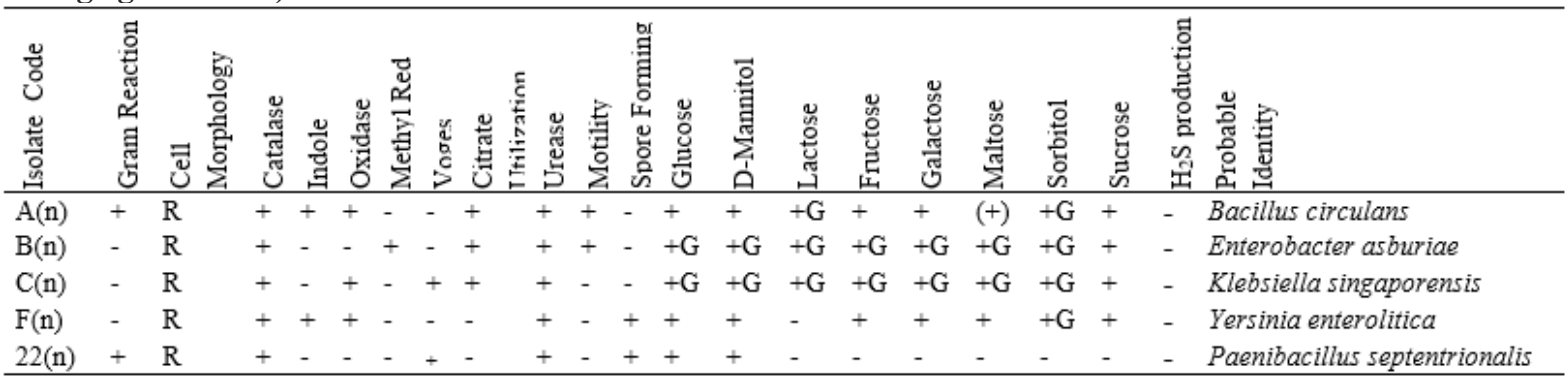

KEY: $\mathrm{R}=\mathrm{Rod}, \mathrm{C}=$ Cocci, $+=$ Positive reaction, $(-)=$ Negative reaction, $(+)=$ weakly positive reaction

Table 11:Microscopic Characterization of Fungi Isolates from Pig Dung (before and after electric current generation)

\begin{tabular}{|l|l|l|}
\hline Isolate Code & \multicolumn{1}{|c|}{ Characteristics } & Probable Identity \\
\hline $\mathbf{1}$ & $\begin{array}{l}\text { It is characterized by thallus which varies in colour, hyaline septate } \\
\text { hyphae, produces both macro- and microconidia from slender } \\
\text { phialides. Microconidia are hyaline, two to several-celled, fusiform to } \\
\text { sickle-shaped, mostly with an elongated apical cell and pedicellate } \\
\text { basal cell. Microconidia are one or two-celled, hyaline, smaller than } \\
\text { macroconidia, fusiform to ovoid. }\end{array}$ & Fusarium sp \\
\hline $\mathbf{2}$ & $\begin{array}{l}\text { Conidiophores stipes are hyaline and coarsely roughened, often more } \\
\text { noticeable near the vesicle, conidial heads globose to subglobose, pale } \\
\text { green and conspicuously echinulate. }\end{array}$ & Aspergillus flavus \\
\hline $\mathbf{3}$ & $\begin{array}{l}\text { Thin, spreading colonies velvety and grass-green to bluish, green with } \\
\text { pale to bright yellow sometimes vinaceous reverse and yellow exudate } \\
\text { conidiophores two-to three-stage branched conidia smooth-walled } \\
\text { odour often fruity conidia are tri-nucleate. }\end{array}$ & chrysogenum \\
\hline $\mathbf{4}$ & $\begin{array}{l}\text { Colonies are typically black, conodiophores arising from long, broad } \\
\text { thick-walled, sosmetimes branched foot cells. It has tall conidiophores } \\
\text { and conidia are large with radiating heads. }\end{array}$ & Aspergillus niger \\
\hline $\mathbf{5}$ & $\begin{array}{l}\text { Conidiophores hyaline or slightly coloured, short green, particularly } \\
\text { in the upper part, smooth-walled, conidial heads radiate to nearly } \\
\text { globose. }\end{array}$ & $\begin{array}{l}\text { Aspergillus } \\
\text { funmigatus }\end{array}$ \\
\hline
\end{tabular}

\section{Physicochemical Composition of Pig Dung}

Physicochemical composition of pig dung from different sites are represented in Table 12. The result indicated that there was a significant difference $(\mathrm{p} \leq 0.05)$ in the physicochemical parameters across the various sites. The $\mathrm{pH}$ ranged from 7.02 to 7.83. Apatapiti Extension pig dung had the lowest value of $7.02 \pm 0.01$ significantly $(\mathrm{p} \leq 0.05)$ while there was no significant $(\mathrm{p} \leq 0.05)$ difference between FUTA and Air Force pig dung with values $7.83 \pm 0.01$ and $7.82 \pm 0.01$ respectively. The electrical conductivity ranged from $897.00 \mu \mathrm{S} / \mathrm{cm}$ to $1097.33 \mu \mathrm{S} / \mathrm{cm}$. FUTA pig dung had the lowest value of $(897.00 \pm 1.15) \mu \mathrm{S} / \mathrm{cm}$ while Air Force pig dung had the highest value of $(1097.33$ 
$\pm 0.67) \mu \mathrm{S} / \mathrm{cm}$ significantly $(\mathrm{p} \leq 0.05)$. The total organic matter ranged from $1.98 \%$ to $3.19 \%$. Apatapiti Extension pig dung had the lowest value of $(1.98 \pm 0.01) \%$ while Air Force pig dung had the highest value of $(3.19 \pm 0.01) \%$ significantly $(\mathrm{p} \leq 0.05)$. The total nitrogen ranged from $0.5800 \%$ to $1.0300 \%$. FUTA pig dung had the lowest value of $(0.58 \pm 0.01) \%$ while Apatapiti Extension pig dung had the highest value of $(1.03 \pm 0.01) \%$ significantly $(\mathrm{p} \leq 0.05)$. The sodium composition ranged from $17.40 \mathrm{mg} / \mathrm{kg}$ to $20.10 \mathrm{mg} / \mathrm{kg}$ with no significant $(\mathrm{p} \leq 0.05)$ difference between FUTA and Apatapiti Extension pig dung having values $(18.50 \pm 0.36) \mathrm{mg} / \mathrm{kg}$ and $(17.40 \pm$ $0.26) \mathrm{mg} / \mathrm{kg}$ respectively while Air Force pig dung had the highest value of $(20.10 \pm 0.32) \mathrm{mg} / \mathrm{kg}$ significantly $(\mathrm{p} \leq 0.05)$. The potassium composition ranged from $35.90 \mathrm{mg} / \mathrm{kg}$ to $42.30 \mathrm{mg} / \mathrm{kg}$. Apatapiti Extension pig dung had the lowest value of $(35.90 \pm 0.31) \mathrm{mg} / \mathrm{kg}$ while Air Force pig dung had the highest value of $(42.30 \pm 0.12) \mathrm{mg} / \mathrm{kg}$ significantly $(\mathrm{p} \leq 0.05)$. The calcium composition ranged from $7.93 \mathrm{mg} / \mathrm{kg}$ to $13.00 \mathrm{mg} / \mathrm{kg}$. Air Force pig dung had the lowest value of $(7.93 \pm 0.09) \mathrm{mg} / \mathrm{kg}$ while Apatapiti Extension pig dung had the highest value of $(13.00 \pm 0.42)$ $\mathrm{mg} / \mathrm{kg}$ significantly $(\mathrm{p} \leq 0.05)$. The magnesium composition ranged from $4.27 \mathrm{mg} / \mathrm{kg}$ to $4.89 \mathrm{mg} / \mathrm{kg}$. FUTA pig dung had the lowest value of $(4.27 \pm 0.01) \mathrm{mg} / \mathrm{kg}$ while Air Force pig dung had the highest value of $(4.89 \pm 0.03)$ $\mathrm{mg} / \mathrm{kg}$ significantly $(\mathrm{p} \leq 0.05)$. The copper composition ranged from $0.14 \mathrm{mg} / \mathrm{kg}$ to $0.33 \mathrm{mg} / \mathrm{kg}$ with no significant $(\mathrm{p} \leq 0.05)$ difference between the copper composition of Air Force and Apatapiti Extension pig dung having values $(0.17 \pm 0.01) \mathrm{mg} / \mathrm{kg}$ and $(0.14 \pm 0.01) \mathrm{mg} / \mathrm{kg}$ respectively while FUTA pig dung had a higher value of $(0.33 \pm$ $0.01) \mathrm{mg} / \mathrm{kg}$ significantly $(\mathrm{p} \leq 0.05)$. The Zinc composition ranged from $0.43 \mathrm{mg} / \mathrm{kg}$ to $0.63 \mathrm{mg} / \mathrm{kg}$. Air Force pig dung had the lowest value of $(0.43 \pm 0.01) \mathrm{mg} / \mathrm{kg}$ while FUTA pig dung had the highest value of $(0.63 \pm 0.01)$ $\mathrm{mg} / \mathrm{kg}$ significantly $(\mathrm{p} \leq 0.05)$. 
Table 12: Physicochemical Composition of Pig Dung

\begin{tabular}{|c|c|c|c|c|c|c|c|c|c|c|}
\hline Pig Dung & pH & EC & TOM & Total N & $\mathrm{Na}$ & $\mathbf{K}$ & $\mathrm{Ca}$ & Mg & $\mathrm{Cu}$ & $\mathrm{Zn}$ \\
\hline \multirow[t]{2}{*}{ FUTA } & $7.8300=$ & $897.0000 \pm$ & $2.3300 \pm$ & $0.5800 \pm$ & $18.5000 \pm$ & $37.5000 \pm$ & $10.4500 \pm$ & $4.2700 \pm$ & $0.3300 \pm$ & $0.6300 \pm$ \\
\hline & $0.00577^{b}$ & $1.15470^{\mathrm{a}}$ & $0.00577^{b}$ & $0.01155^{\mathrm{a}}$ & $0.36056^{\mathrm{a}}$ & $0.30000^{\mathrm{b}}$ & $0.02082^{b}$ & $0.01155^{\mathrm{a}}$ & $0.01000^{\mathrm{b}}$ & $0.01000^{c}$ \\
\hline \multirow[t]{2}{*}{ Air Force } & $7.8200 \pm$ & 1097.3333 & $3.1900 \pm$ & $0.9200 \pm$ & $20.1000 \pm$ & $42.3000 \pm$ & $7.9333 \pm$ & $4.8900 \pm$ & $0.1700 \pm$ & $0.4300 \pm$ \\
\hline & $0.00577^{b}$ & $\pm 0.66667 \mathrm{c}$ & $0.01155^{c}$ & $0.00577^{b}$ & $0.32146^{b}$ & $0.11547^{c}$ & $0.08819^{\mathrm{a}}$ & $0.02646^{c}$ & $0.01155^{\mathrm{a}}$ & $0.01000^{\mathrm{a}}$ \\
\hline Apatapiti & $7.0233 \pm$ & $945.0000 \pm$ & $1.9800 \pm$ & $1.0300 \pm$ & $17.4000 \pm$ & $35.9000 \pm$ & $13.0000 \pm$ & $4.5200 \pm$ & $0.1400 \pm$ & $0.4900 \pm$ \\
\hline Extension & $0.00882^{\mathrm{a}}$ & $1.15470^{b}$ & $0.01155^{\mathrm{a}}$ & $0.01528^{c}$ & $0.26458^{\mathrm{a}}$ & $0.30551^{\mathrm{a}}$ & $0.41633^{c}$ & $0.01000^{\mathrm{b}}$ & $0.01155^{\mathrm{a}}$ & $0.01155^{b}$ \\
\hline
\end{tabular}

Values are means \pm Standard error of pig dung. Values in the same column carrying the same superscript are not significantly different at $(\mathrm{p} \leq 0.05)$ using Duncan's New Multiple Range Test.

KEY:

\begin{tabular}{|c|c|c|c|}
\hline $\begin{array}{l}\text { EC- Electrical Conductivity } \\
\text { Copper }\end{array}$ & TOM- Total Organic Matter & Mg- Magnesium & K- Potassium \\
\hline $\begin{array}{l}\mathrm{pH} \text { - Hydrogen ion Concentration } \\
\text { Calcium }\end{array}$ & N- Nitrogen & Zn- Zinc & Na- Sodium \\
\hline
\end{tabular}

\section{Voltage Generated from FUTA Pig Dung}

The voltage generated from FUTA pig dung is represented in Figure 1. There was a significant difference $(p \leq 0.05)$ in the voltage generated across the three sessions of the day. FUTA pig dung (morning session) generated significantly $(\mathrm{p} \leq 0.05)$ its lowest voltage on day 3 with the value of $43.0000 \pm 0.57735 \mathrm{mV}$ while its highest voltage was generated on days 17 and 29 with values $500.0000 \pm 0.57735 \mathrm{mV}$ and $496.0000 \pm 0.57735 \mathrm{mV}$ respectively. FUTA pig dung (afternoon session) generated significantly $(\mathrm{p} \leq 0.05)$ its lowest voltage on day 3 with the value of $87.0000 \pm 0.57735 \mathrm{mV}$ while its highest voltage was generated on days 17 and 29 with values $501.0000 \pm 0.57735$ $\mathrm{mV}$ and $497.6667 \pm 0.88192 \mathrm{mV}$ respectively. FUTA pig dung (evening session) generated significantly $(\mathrm{p} \leq 0.05)$ its lowest voltage on day 1 with the value of $21.6667 \pm 0.57735 \mathrm{mV}$ while its highest voltage was generated on day 17 with the value of $497.6667 \pm 0.57735 \mathrm{mV}$.

\section{Current Generated from FUTA Pig Dung}

The current generated from FUTA pig dung is represented in Figure 2. There was a significant difference $(p \leq 0.05)$ in the current generated across the three sessions of the day. FUTA pig dung (morning session) generated significantly $(\mathrm{p} \leq 0.05)$ its lowest current on days 2 and 4 with the value of $0.0163 \pm 0.00088 \mathrm{~mA}$ and $0.0177 \pm$ $0.00088 \mathrm{~mA}$ respectively while its highest current was generated on days 26 and 28 with values $0.1817 \pm 0.00088$ $\mathrm{mA}$ and $0.1813 \pm 0.00578 \mathrm{~mA}$ respectively. FUTA pig dung (afternoon session) generated significantly $(\mathrm{p} \leq 0.05)$ its lowest current on days 3 and 6 with values $0.0157 \pm 0.00285 \mathrm{~mA}$ and $0.0173 \pm 0.00120 \mathrm{~mA}$ respectively while its highest current was generated on days 26 and 28 with values $0.1880 \pm 0.00058 \mathrm{~mA}$ and $0.1877 \pm 0.00120 \mathrm{~mA}$ respectively. FUTA pig dung (evening session) generated significantly $(\mathrm{p} \leq 0.05)$ its lowest current on days 7 and 8 with values of $0.0220 \pm 0.00058 \mathrm{~mA}$ and $0.0220 \pm 0.00058 \mathrm{~mA}$ respectively while its highest current was generated on day 9 with the value of $0.3130 \pm 0.00153 \mathrm{~mA}$.

\section{Voltage Generated from Apatapiti Extension Pig Dung}

The voltage generated from Apatapiti Extension pig dung is represented in Figure 3. There was a significant difference $(\mathrm{p} \leq 0.05)$ in the voltage generated across the three sessions of the day. Apatapiti Extension pig dung (morning session) generated significantly $(\mathrm{p} \leq 0.05)$ its lowest voltage on day 9 with the value of $182.0000 \pm$ $1.15470 \mathrm{mV}$ while its highest voltage was generated on day 17 with a value of $523.0000 \pm 0.57735 \mathrm{mV}$. Apatapiti Extension pig dung (afternoon session) generated significantly $(\mathrm{p} \leq 0.05)$ its lowest voltage on day 9 with the value of $185.6667 \pm 1.45297 \mathrm{mV}$ while its highest voltage was generated on day 17 with a value of $527.3333 \pm 0.57735$ $\mathrm{mV}$. Apatapiti Extension pig dung (evening session) generated significantly $(\mathrm{p} \leq 0.05)$ its lowest voltage on day 4 with the value of $114.3333 \pm 2.33333 \mathrm{mV}$ while its highest voltage was generated on day 17 with the value of $522.3333 \pm 1.20185 \mathrm{mV}$.

\section{Current Generated from Apatapiti Extension Pig Dung}

The current generated from Apatapiti Extension pig dung is represented in Figure 4. There was a significant difference $(\mathrm{p} \leq 0.05)$ in the voltage generated across the three sessions of the day. Apatapiti Extension pig dung (morning session) generated significantly $(\mathrm{p} \leq 0.05)$ its lowest current on day 6 with a value of $0.0520 \pm 0.001155$ $\mathrm{mA}$ while its highest current was generated on day 26 with a value of $0.3190 \pm 0.00058 \mathrm{~mA}$. Apatapiti Extension pig dung (afternoon session) generated significantly $(\mathrm{p} \leq 0.05)$ its lowest current on days 2 and 3 with the value of $0.0570 \pm 0.000577 \mathrm{~mA}$ and $0.0607 \pm 0.000882$ while its highest current generation was on day 26 with a value of 
$0.3123 \pm 0.006173 \mathrm{~mA}$. Apatapiti Extension pig dung (evening session) generated significantly ( $\mathrm{p} \leq 0.05)$ its lowest current on day 2 with a value of $0.0530 \pm 0.001528 \mathrm{~mA}$ while its highest current was generated on day 26 with the value of $0.3140 \pm 0.00058 \mathrm{~mA}$.

\section{Voltage Generated from Air Force Pig Dung}

The voltage generated from Air Force pig dung is represented in Figure 5. There was a significant difference $(\mathrm{p} \leq 0.05)$ in the voltage generated across the three sessions of the day. Air Force pig dung (morning session) generated significantly $(\mathrm{p} \leq 0.05)$ its lowest voltage on day 9 with the value of $111.0000 \pm 0.57735 \mathrm{mV}$ while its highest voltage was generated on day 13 with a value of $522.0000 \pm 0.57735 \mathrm{mV}$. Air Force pig dung (afternoon session) generated significantly $(\mathrm{p} \leq 0.05)$ its lowest voltage on day 1 with the value of $151.0000 \pm 0.57735 \mathrm{mV}$ while its highest voltage was generated on day 12 with a value of $572.3333 \pm 3.84418 \mathrm{mV}$. Air Force pig dung (evening session) generated significantly $(\mathrm{p} \leq 0.05)$ its lowest voltage on day 4 with the value of $161.0000 \pm 0.57735$ $\mathrm{mV}$ while its highest voltage was generated on days 12 and 13 with the value of $524.0000 \pm 0.57735 \mathrm{mV}$ and $524.6667 \pm 0.3333 \mathrm{mV}$ respectively.

\section{Current Generated from Air Force Pig Dung}

Current generated from Air Force pig dung is represented in Figure 6. The result showed that there was a significant difference $(\mathrm{p} \leq 0.05)$ in the current generated across the three sessions of the day. Air Force pig dung (morning session) generated significantly $(\mathrm{p} \leq 0.05)$ its lowest current on days 2 and 6 with values $0.04200 \pm 0.001155 \mathrm{~mA}$ and $0.04267 \pm 0.00176 \mathrm{~mA}$ respectively while its highest current was generated on day 9 with a value of $0.2760 \pm$ $0.001155 \mathrm{~mA}$. Air Force pig dung (afternoon session) generated significantly $(\mathrm{p} \leq 0.05)$ its lowest current on day 2 with a value of $0.03400 \pm 0.00115 \mathrm{~mA}$ while its highest current was generated on day 8 with a value of $0.14233 \pm$ $0.00145 \mathrm{~mA}$. Air Force pig dung (evening session) generated significantly $(\mathrm{p} \leq 0.05)$ its lowest current on day 2 with a value of $0.03067 \pm 0.00033 \mathrm{~mA}$ while its highest current was generated on day 9 with the value of 0.25167 $\pm 0.00202 \mathrm{~mA}$.

\section{Voltage Generated from Control MFC}

The voltage generated from control MFC with $\mathrm{KMnO}_{4}$ and $\mathrm{H}_{2} \mathrm{O}$ as electron acceptor are shown in Figures 7 respectively. The result showed that there was a significant difference in the $(\mathrm{p} \leq 0.05)$ in the voltage generated daily, the highest voltage was generated on day 1 for both $\mathrm{MFC}$ with $\mathrm{KMnO}_{4}$ and $\mathrm{H}_{2} \mathrm{O}$ as electron acceptor with values $379.00 \pm 0.00 \mathrm{mV}$ and $183.33 \pm 0.00 \mathrm{mV}$ respectively after which there was a steady decrease to the minimum values on days 8 and 6 respectively.

\subsection{Current Generated from Control MFC}

The current generated from control MFC with $\mathrm{KMnO}_{4}$ and $\mathrm{H}_{2} \mathrm{O}$ as electron acceptor are shown in Figures 8 respectively. The result showed that there was a significant difference in the $(p \leq 0.05)$ in the voltage generated daily, the highest current was generated on day 1 for both $\mathrm{MFC}$ with $\mathrm{KMnO}_{4}$ and $\mathrm{H}_{2} \mathrm{O}$ as electron acceptor with values $0.030 \pm \mathrm{mA}$ and $0.211 \pm 0.00 \mathrm{~mA}$ respectively after which there was a steady decrease to the minimum values on days 8 and 6 respectively.

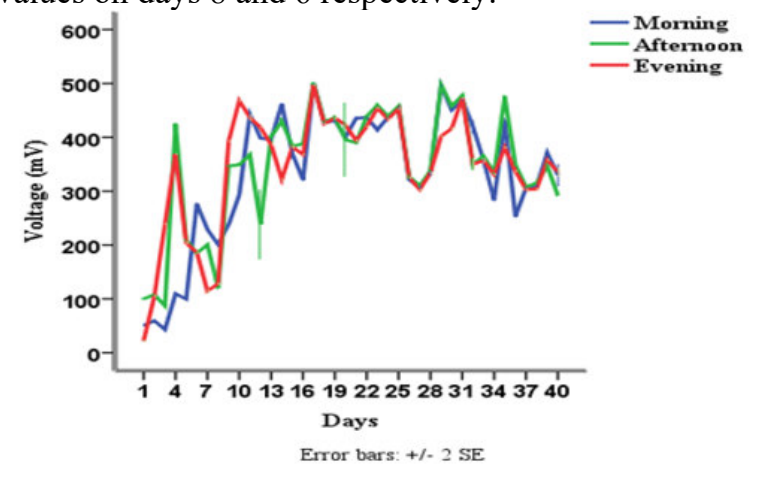

Figure 1: Voltage from Futa pig dung within 40 days

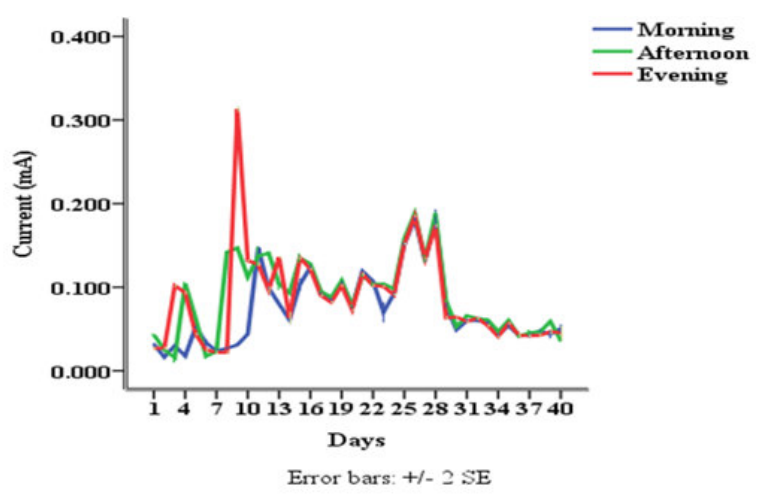

Figure 2: Current from Futa pig dung within 40 days 


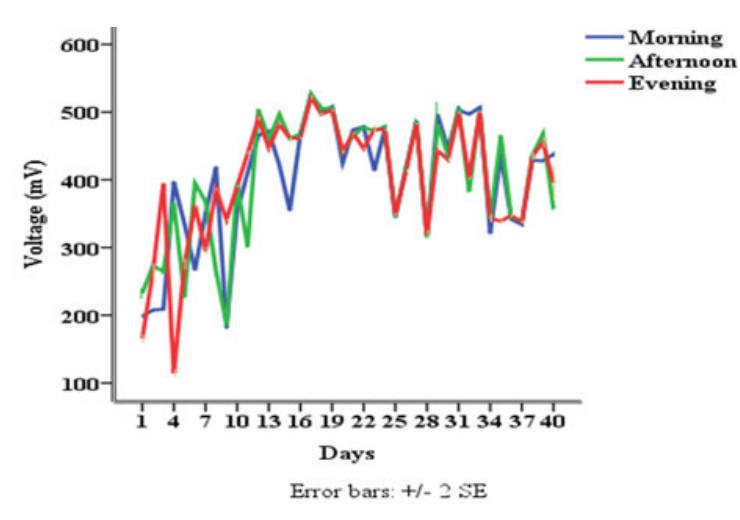

Figure 3: Voltage from Apatapiti pig dung within 40 days

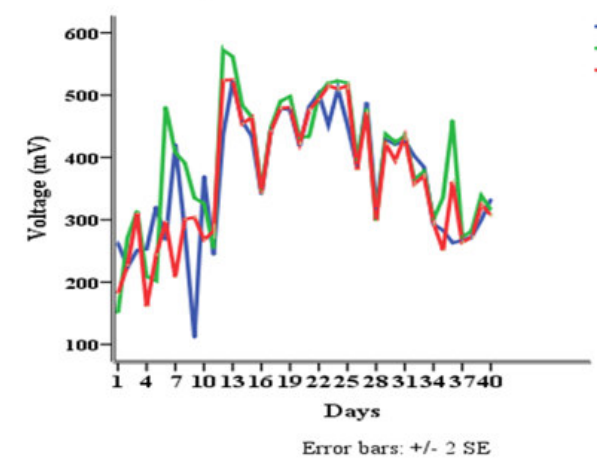

Figure 5: Voltage from Air Force pig dung within 40 days

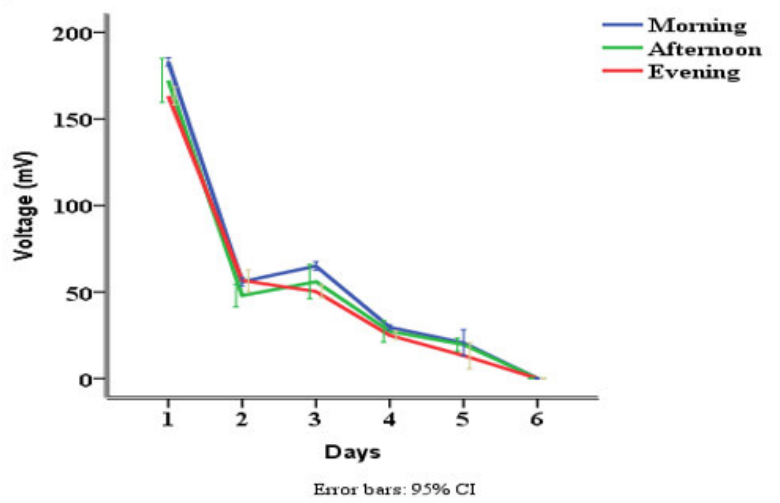

Figure 7: Voltage from Control pig dung

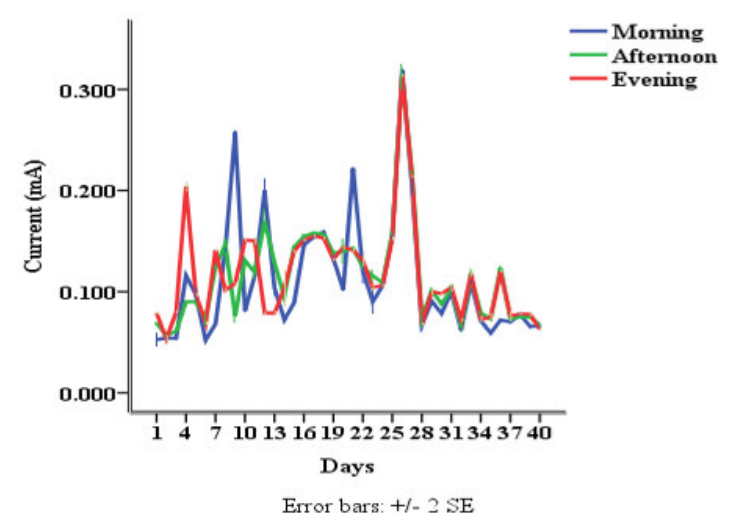

Figure 4: Current from Apatapiti pig dung within 40 days

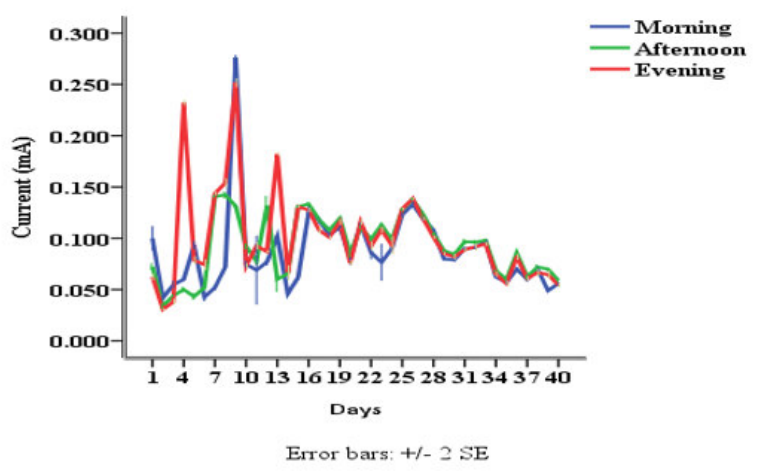

Figure 6: Current from Air Force pig dung within 40 days

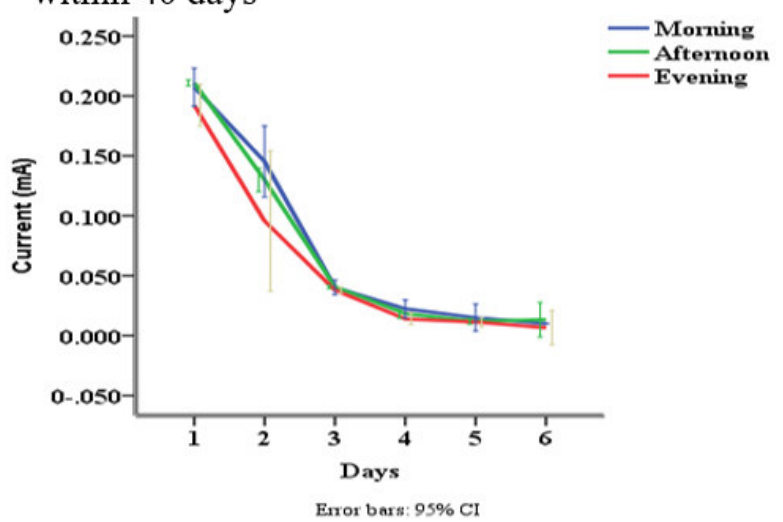

Figure 8: Current from Control pig dung

\section{Discussion}

In this study, the potential of pig dung from FUTA, Air Force and Apatapiti Extension to produce current and voltage using a microbial fuel cell was evaluated. The microbial population obtained in this study under aerobic and anaerobic condition showed that pig dung is a natural host for bacteria and fungi, this agrees with the report of (Onuorah et al., 2017). The authors studied the biodeterioration potentials of microorganisms isolated from pig manure and reported the presence of diverse bacteria and fungi which will be useful in remediating oil-polluted environments when applied singly and as consortia. Pig dung from Air Force had the highest bacteria load; this was probably due to its significantly highest organic matter content than the other two samples. Bacteria counts were much higher than the fungi count in all the pig dung samples, the high bacteria load obtained agrees with the 
report of Onuorah et al. (2017). The authors reported that pig manure contains a teaming population of heterotrophic bacteria. Coliform organisms were present in all the pig dung samples at a population intermediate to bacteria and fungi counts, this is because coliform bacteria are key faecal indicator microorganisms (Lim et al., 2018). The level of coliform present implies that the use of pig dung for electricity may pose human and animal health hazard if not properly managed (Trawinska et al., 2015).

The results of the final isolation from the anodic chambers of the MFCs after 40 days of current and voltage generation showed that all the microbial fuel cells maintained a moderate population of bacteria, fungi and coliforms throughout the experiment, this implies that these microorganisms are indeed responsible for the continuous generation of the electric voltage and current ditto to their presence before and after current and voltage generation; this agrees with the findings of (Kumar et al., 2012). The authors studied electricity generation from cow dung using microbial fuel cell and established that the bacteria present in it could engage the anode in their metabolism, resulting in bioelectricity generation. Microorganisms present before and after the electric energy period was an indicator of their decomposing ability and ability to tolerate little or no oxygen (i.e. live in an anaerobic condition) which conferred on them the surviving ability during the period, this conforms to the findings of (Lim et al., 2018). The authors stated that the various microorganisms that are present in pig slurry play a vital role in the decomposition of manure, these organisms live in a partially anaerobic environment and therefore utilize a variety of potential substrates, including proteins and non-starch polysaccharides. Microorganisms interact with the pig dung in the MFC as their source of nutrients and energy for growth which effectuated the microbial decomposition of the pig dung and simultaneous release of electrons, protons and $\mathrm{CO}_{2}$ under anaerobic oxidation; this is the mechanism of operation in a typical microbial fuel cell and corroborates with the description of (Sharma and Bulchandani, 2012). The authors reported that microbial fuel cell is a device that converts chemical energy from the bio-convertible organic substrate, directly into electrical energy through the metabolic activities of microorganisms. However, in this study, higher microbial load was recorded for cultivation under aerobic condition compared to cultivation under anaerobic condition throughout the study, this observation is in agreement with that of (Pa'dua Ferreira et al., 2011). The authors reported higher bacterial counts observed in aerobic condition in comparison with anaerobic conditions.

There was a relative decline in the bacterial and coliform load of all MFCs after current and voltage generation under both aerobic and anaerobic condition in comparison to the initial load obtained from all the pig dung samples. This was possible because it was expected that after 40 days of electric current and voltage generation under anaerobic condition, nutrients becomes less available, waste products released from the microorganisms increase, secondary metabolites are released, and the number of dying cells continues to rise; this is a typical description of the death phase of microbial growth curve. In the death phase, the number of living cells decreases exponentially and population growth experiences a sharp decline, adaptation and succession takes place; as dying cells lyse or break open, they spill their contents into the environment making these nutrients available to other bacteria. This helps spore-producing bacteria to survive long enough for spore production. Spores are able to survive the harsh conditions of the death phase and become growing bacteria when placed in an environment that supports life (Nina et al., 2017). This was not the same for the fungi population in the MFCs of the three pig dung samples after current and voltage generation, there was an increase in fungi population in the Apatapiti MFC, this can be attributed to the ability of spores to survive longer in harsh condition according to Nina et al. (2017), no growth was recorded in FUTA MFCs, and there was neither increase nor decrease in the Air Force MFCs compared to the initial fungal load from the pig dung (Paul et al., 2019).

There was a decline in the population of the microbial community between the initial and final isolation. This is possible as a result of microbial adaptation, succession and evolution which are likely to have taken place in the anode chamber of the MFC within the 40 days period of current and voltage generation, this naturally occurs in response to environmental changes dictating the survival, elimination or evolution of the members in the microbial community (Zegeye et al., 2019). All the identified bacteria at the phylum level can be classified into three which include the phylum Firmicute, the phylum Proteobacteria and the phylum Actinobacteria. Bacillus sp belonging to the phylum Firmicutes was the dominating organism in both the initial and final isolation; this agrees with the report of Lim et al. (2018), they studied the effects of temperature and storage time on the evolution of bacterial communities in pig manure, and identified the bacterial community on phylum basis to consist of the phylum Firmicute, the phylum Proteobacteria and the phylum Actinobacteria and as well reported that Firmicutes was the dominant phylum in all samples (ranging from $89.3 \%$ to $98.8 \%$ of the total isolate identified).

These microorganisms are facultative anaerobes which can grow under aerobic and anaerobic condition because there was growth from all the microbial fuel cells when cultivated under both aerobic and anaerobic condition; this agrees with the work of Lim et al. (2018) in their evaluation of pig slurry, they stated that microorganisms live in a partially anaerobic environment and therefore utilize a variety of potential substrates, including proteins and non-starch polysaccharides. Stieglmeier et al. (2009) also reported about facultative anaerobes when isolated on anaerobic and aerobic media are capable of growing under both conditions.

The $\mathrm{pH}$ of Apatapiti Extension pig dung, Air Force pig dung and FUTA pig dung were within the range of 
slightly neutral to slight alkalinity (7.02 to 7.83). The result obtained is in consonance with the report by Marszałek et al. (2014), who stated that the reaction of typical pig slurry is usually slightly alkaline, they compared the $\mathrm{pH}$ of pig slurry from about seven countries which ranged from 7.05 to 8.11.

The mineral composition of the pig dung showed variation across the different pig dung samples. The presence of sodium, potassium, calcium, zinc, copper, magnesium and total nitrogen in the pig dung is similar to the findings of Marszałek et al. (2014) and Okoli et al. (2019), they identified the presence of macro-minerals such as potassium, calcium, sodium, nitrogen, magnesium; trace minerals such as copper and zinc in pig dung. The total nitrogen composition in the pig dung was lower than the value recorded by Okoli et al. (2019) but higher than the value reported by Marszałek et al. (2014). All the pig dung samples were considerably high in the potassium content, this is possibly due to high potassium content in the palm kernel cake and forage which constitute the bulk of their feed because it is cheap and readily available (Okoli et al., 2019). These findings conform to the work of Okoli et al. (2019), they reported that pig dung was high in potassium and low in other minerals and the findings of Okoli et al. (2011) reported a high level of potassium in the pig dung in their study area. Udebuani et al. (2012), however reported much higher calcium, magnesium and phosphorus values than the present result. Samples in this study were generally much higher in zinc content than the other micro-elements, this agrees with the findings of Udebuani et al. (2018). They reported a higher zinc value among the micro-minerals but the value in this present study is much higher than the high value recorded in their study.

Presence of the salts of these minerals within the pig dung may be responsible for the high electrical conductivity (EC) in all the samples (Fitzgerald and Racz, 2001). Electrical conductivity was generally high in all the samples. However, pig dung from Air Force had the highest electrical conductivity $(1098.00 \mu \mathrm{S} / \mathrm{cm})$, this can be attributed to its highest values of mineral salts (sodium, potassium, calcium and magnesium) above the other samples. This agrees with the report of Fitzgerald and Racz (2001), they stated that electrical conductivity is an indicator of the total soluble salt concentration, it can be high mainly because of the presence of water-soluble nutrients and the dominant ions that contribute to electrical conductivity of manures are $\mathrm{NH}_{4}, \mathrm{Na}, \mathrm{Ca}, \mathrm{Mg}, \mathrm{K}, \mathrm{Cl}$, sulphate and bicarbonate.

In the study, the current and voltage generated across the observation period (40 days) from most of the samples were in a sinusoidal manner on graphic representation with irregular falls and rises (indicating increase and decrease at irregular intervals). This disagrees with the steady and gradual increase throughout the observation period (10 days) in the work of Meignanalakshmi et al. (2013) and the progressive increase in the generation period (14 days) reported in the work of Adegunloye and Ojo (2019), when decayed wood was used for current and voltage generation.

Highest voltage and current were generated from the pig dung samples at varying times. Pig dung from Air Force generated the highest voltage $(572 \mathrm{mV})$ across all the MFC, this was recorded in the afternoon session of day 12 . This is higher than the maximum voltage $(330 \mathrm{mV})$ obtained from the $\mathrm{MFC}$ (with $\mathrm{H} 2 \mathrm{O}$ as electron acceptor) for swine waste samples in the work of (Meignanalakshmi et al., 2013). Pig dung from Apatapiti Extension generated the highest current $(0.319 \mathrm{~mA})$ across all the MFCs, this was recorded in the evening session of day 20. This is close to the maximum current (0.330) $\mathrm{mA}$ obtained from the MFC (with $\mathrm{H}_{2} \mathrm{O}$ as electron acceptor) for pig waste samples in the work of (Meignanalakshmi et al., 2013).

Generation of low voltage and current from control MFC revealed that chemical and biological factors based on difference of potential between the two chambers might be responsible for this voltage and current generated. Thereafter, the voltage and current rapidly decreased due to absence of microorganisms for biological activities unlike in other MFCs where the presence of microorganisms enabled increase and continuous generation of current and voltage. This is similar to the report of (Akujobi et al., 2017).

\section{Conclusion}

The potential of generating electricity from pig dung as an additional alternative electrical energy was evaluated in this study. From the result and observation obtained, pig dung contained a consortia of microbial flora capable of oxidizing its organic matter constituent to produce electrical energy via MFC technology. The current and voltage generated was comparable to those reported for other substrates. Hence, electricity generation using a waste like pig dung via this technology is a promising alternative for electricity generation. We hereby recommend its evaluation at large scale in other to harness this as an alternative and additional sources of electricity.

\section{REFERENCES}

Adegunloye, D. V. and Olotu, T. M. (2017). Generating Electricity Using Microbial Fuel Cell Powered by Benthic Mud Collected From Two Locations in Akure, Nigeria. European Scientific Journal, 13: 18

Adegunloye, D. V. and Ojo, I. M. (2019). Electricity Production Potential of Decayed Tectona grandis Using Microbial Fuel Cell. Journal of Advances in Microbiology, 14(3): 1-8

Akujobi, C. O., Anuforo, H. U., Ogbulie, T. E. and Ezeji, E. U. (2017). Study on Generation of Bioelectricity Using Potassium Ferricyanide Electron Acceptor in Microbial Fuel Cell. Chemical and Biomolecular 
Engineering, 2(1): 5-13

Cao, Y., Mu, H., Liu, W., Zhang, R., Guo, J., Xian, M. and Liu, H. (2019). Electricigens in the anode of microbial fuel cells: pure cultures versus mixed communities. Microbial Cell Factories, 18: 39

Cheesbrough, M. (2006). Biochemical tests to identify bacteria. In: Cheesbrough M. (ed.) District laboratory practice in tropical countries, Part 2, $2^{\text {nd }}$ Edition. Cambridge University Press, UK. 7: 62-70

Fan, L. P. and Xue, S. (2016). Overview on Electricigens for microbial Fuel Cell. The Open Biotechnology Journal, 10: $398-406$

Fawole, M. O. and Oso, B. A. (2012). Laboratory Manual of Microbiology, Spectrum books limited. 2: 112-121

Fitzgerald, M. M. and Racz. G. J. (2001). Long term effects of hog manure on soil quality and productivity. Report to the Agri-Food Research and Development Initiative (ARDI). April 2001, Pp 1-72

Franks, A. E. and Nevin, K. P. (2010). Microbial fuel cells, a current review. Energies, 3(5): 899-919

Iregbu, G. U., Kubkomawa, I. H., Okoli, C. G., Ogundu, E. C., Uchegbu, M. C. and Okoli, I. C. (2014). Environmental concerns of pig waste production and its potentials as biofuel source. Journal of Animal and Veterinary Sciences, 13: 17-24

Kim, H. J., Park, H. S. Hyun, M. S., Chang, I. S., Kim, M. and Kim, B. J. (2002) A mediatorless microbial fuel cells using a metal reducing bacterium, Shewanella putrefaciens. Enzyme Microbiology Technology, 30(2): $145-152$

Kumar, S., Kumar, H. D. and Babu K. G. (2012). A study on the electricity generation from the cow dung using microbial fuel cell. Journal of Biochemical Technology, 3(4): 442-447

Lim, J.S., Yang, S.H., Kim, B.S. and Lee, E.Y. (2018). Comparison of microbial communities in swine manure at various temperatures and storage times. Asian-Australasian Journal of Animal Sciences, 31(8): 1373-1380

Liu, H., Cheng, S. and Logan, B. E. (2005) Production of electricity from acetate or butyrate using a singlechambers microbial fuel cell. Environmental Science and Technology, 39: 658-662

Marszałek, M., Kowalski, Z. and Makara, A. (2014). Physicochemical and Microbiological Characteristics of Pig Slurry. Technical Transactions Chemistry, Pp 82-91

Meignanalakshmi, S., Deepika, J. and Deana, D. (2013). Bioelectricity Production From Lysinibacillus Sphaericus Dms-3 Isolated From Swine Waste. International Journal of Advanced Biotechnology and Research, 4(3): 291-295

Nina, P., Mark, S., Thi Tu, A., Brian, M. F. and Philip, L. (2017). Microbiology. Open Stax, Rice University.

Okoli, I. C., Uchegbu, M. C., Alaoma, O. R., Omede, A. A., Opara, M. N. and Ekenyem, B. U. (2011). Compositional and biochemical characteristics of grower pig rations compounded by small holder pig farmers in Imo State, Nigeria. Proceedings of the 3rd International Conference on Sustainable Animal Agriculture for Developing Countries, July 26-29, 2011, Nakhon Ratchasima, Thailand.

Okoli, C. G., Edo, F. A. Ogbuewu, I. P., Nwajiobi, I. J., Enemor, V. H. A. and Okoli, I. C. (2019). Biochemical values of pig dung collected from different locations in Imo state, southeastern Nigeria. Asian Journal of Biological Sciences, 12: 470-476

Onuorah, S., Soludo, C. and Odibo, F. (2017). Biodeterioration Potentials of Microorganisms Isolated from Pig Manure Obtained at Awka, Nigeria. Natural Resources and Conservation, 5(3): 33-43

Oyedepo, S. O. (2012). Energy and sustainable development in Nigeria: the way forward. Energy, Sustainability and Society, 2: 15

Pa'dua Ferreira, R. V., Sakata, S. K., Isiki, V. L. K., Miyamoto, H., Bellini, M. H., Lima, L. F. C. P. and Marumo, J. T. (2011). Influence of americium-241 on the microbial population and biodegradation of organic waste. Environmental Chemistry Letters, 9(2): 209-216

Paul, C., Filippidou, S., Jamil, I., Kooli, W., Geoffrey L. H., Estoppey, A., Hayoz, M., Junier, T., Palmieri, F., Wunderlin, T., Lehmann, A., Bindschedler, S., Vennemann, T., Chain, P. S. and Junier, P. (2019). Bacterial Spores from Ecology to Biotechnology. Advances in Applied Microbiology, 106: 79-111

Sharma, K., and Bulchandani, B. (2012). Comparative Study of Various Substrates and Microorganisms in a Laboratory Designed Microbial Fuel Cell. Int. J. Res. Chem. Environ, 2(3): 168-174

Stieglmeier, M., Wirth, R., Kminek, G. and Moissl-Eichinger, C. (2009). Cultivation of Anaerobic and Facultatively Anaerobic Bacteria from Spacecraft-Associated Clean Rooms. Applied and Environmental Microbiology, 75: 3484-3491

Trawinska, B., Jozwik, M., Nowakowicz-Debek, B., Chmielowiec-Korzeniowska, A., Lechowski, J., Tymczyna, L. and Magdalena, P. (2015). Effect of Pig Farm on Microbial Contamination of Soil. Annals of Animal Science, 15(1): 165-175

Udebuani, A. C., Okoli, C. I., Nwigwe, H. C. and Ozoh. P. T. E. (2012). The value of animal manure in the enhancement of bioremediation processes in petroleum hydrocarbon contaminated agricultural soils. Journal of Agricultural Technology, 8(6): 1935-1952

Udebuani, A. C., Nwajiobi, I. J., Okoli, I. C. and Ozor, P. T. E. (2018). Proximate and elemental compositions of animal dung collected from Owerri, Southeast Nigeria. Proceedings of the 43rd Annual Conference of the 
Nigerian Society for Animal Production, FUT Owerri, Nigeria, Pp. 1439-1441

Zegeye, E. K., Brislawn, C. J., Farris, Y., Fansler, S. J., Hofmockel, K. S., Jansson, J. K., Wright, A. T., Graham, E. B., Naylor, D., McClure, R. S. and Bernstein, H. C. (2019). Selection, succession, and stabilization of soil microbial consortia. mSystems, 4(4): e00055-19

Zou, Y. J., Sun, L. X., Xu, F. Q. and Yang, L. N. (2007). E.coli microbial fuel cell using new methylene blue as electron mediator. Chemical Journal of Chinese Universities, 28(3): 510-513 